\title{
CUTTING TOOL PERFORMANCE IN TURNING OF AL 7075-T651 ALUMINIUM ALLOY
}

\author{
Nur Sofwati Daud @Ab AzIz ${ }^{1}$, NATASha A. RaOF ${ }^{*}$, \\ Abdul Rahman A.GHANI ${ }^{2}$, Aishah NaJiah Dahnel ${ }^{1}$, Suhaily MoKhtaR ${ }^{1}$, \\ NOR KHAIRUSSHIMA MUHAMAD KHAIRUSSALEH ${ }^{1}$ \\ ${ }^{1}$ Department of Manufacturing and Materials Engineering, \\ International Islamic University Malaysia, Kuala Lumpur, Malaysia. \\ ${ }^{2}$ Production Technology, German Malaysian-Institute, Kuala Lumpur, Malaysia. \\ *Corresponding author: natashar@iium.edu.my
}

(Received: 28 th August 2019; Accepted: $22^{\text {nd }}$ January 2020; Published on-line: $4^{\text {th }}$ July 2020)

\begin{abstract}
Recently, almost $70 \%$ of a commercial jetliner's airframe is made of aluminium alloys. It is predicted that the application of aluminium alloy is to increase up to $65 \%$ by the year 2025 . They are typically used because of their high strength to weight ratio. However, there are some drawbacks during machining aluminium alloy such as the adhesion wear and built-up edge (BUE) formation that can shorten tool life. As the tool wears, the machining performance, surface roughness, and cutting tool life are affected significantly. A lot of studies were conducted in order to minimize this critical issue. This project presents a study of the cutting tool performance of an uncoated carbide tool in dry turning operation on Al 7075-T651, in which the tool wear rate, volume of material removed, wear mechanism, and surface roughness were investigated. The machining tests were conducted on a CNC lathe machine to obtain the tool wear and surface roughness of the machined work piece. The average flank wear was measured using a digital microscope, whereas the wear mechanism was observed using a Scanning Electron Microscope (SEM). The average surface roughness (Ra) was measured using a surface roughness tester. The cutting time for this experiment was fixed at 40 minutes and all the results were analysed within this time range to evaluate the tool performance in the turning of $\mathrm{Al}$ 7075-T651. The results revealed that the tool performs better at low cutting speed, $250 \mathrm{~m} / \mathrm{min}$, by reducing the tool wear rate by $33 \%$. The cutting speed of $250 \mathrm{~m} / \mathrm{min}$ also contributed to $71 \%$ higher volume of material removed during the machining tests. The dominant type of wear found was flank wear, while the main principal of wear mechanism is adhesion. At higher cutting speed, the surface roughness was improved. Based on the results, it can be concluded that high cutting tool performance is achieved when low tool wear growth rate, high volume of material removal, and low surface roughness during turning operation are obtained.
\end{abstract}

ABSTRAK: Kebelakangan ini, hampir 70\% kerangka pesawat udara komersil diperbuat daripada aloi aluminium. Penggunaan aloi aluminum ini dijangka meningkat sehingga $65 \%$ pada tahun 2025. Ia biasa digunakan kerana nisbah kekuatan kepada berat yang tinggi. Walau bagaimanapun, terdapat beberapa kekurangan semasa pemesinan aloi aluminum ini iaitu pemakaian pelekat dan pembentukan binaan tepi (BUE) yang mengurangkan jangka hayat mata alat. Apabila mata alat menjadi haus, prestasi mesin, kekasaran permukaan, dan jangka hayat mata alat pemotong terjejas dengan ketara. Banyak kajian telah dijalankan bagi mengurangkan isu kritikal ini. Projek ini mengkaji prestasi mata alat pemotong karbida tidak bersalut dalam operasi mesin larik kering pada Al 7075-T651, di mana kadar haus mata alat, kuantiti bahan yang dibuang, mekanisme haus dan kekasaran permukaan telah diselidiki. Ujian pemesinan dijalankan pada mesin 
CNC mesin larik bagi mendapatkan kadar haus mata alat dan kekasaran permukaan material yang dimesin. Purata haus pengapit mata alat diukur dengan menggunakan mikroskop digital, manakala mekanisme haus dipantau menggunakan Mikroskop Elektronik Pengimbas (SEM). Purata kekasaran permukaan (Ra) diukur menggunakan alat penguji kekasaran permukaan. Tempoh masa pemotongan bagi eksperimen ini telah ditetapkan pada 40 minit dan semua keputusan telah dianalisa dalam tempoh masa ini bagi menilai prestasi mata alat dalam melarik Al 7075-T651. Hasil menunjukkan prestasi mata alat lebih baik pada kelajuan pemotongan rendah, $250 \mathrm{~m} / \mathrm{min}$ dengan mengurangkan kadar haus mata alat sehingga 33\%. Kelajuan pemotongan $250 \mathrm{~m} / \mathrm{min}$ juga menyumbang kepada $71 \%$ peningkatan ke atas jumlah bahan yang dibuang semasa ujian pemesinan. Jenis haus yang dominan telah ditemui pada pengapit mata alat, manakala mekanisme haus yang utama adalah lekatan. Pada kelajuan pemotongan yang tinggi, kekasaran permukaan didapati lebih baik. Berdasarkan keputusan, dapat disimpulkan bahawa prestasi mata alat pemotong yang bagus dapat dicapai apabila kadar haus mata alat adalah rendah, jumlah penyingkiran bahan yang tinggi dan kekasaran permukaan yang rendah semasa operasi pelarikan dijalankan.

KEYWORDS: tool wear; cutting tool performance; surface roughness; wear mechanism; Al 7075

\section{INTRODUCTION}

Aluminium alloy is one of the common metal alloys used to manufacture products in industries such as automotive, aircraft, sporting equipment, food packaging, and building construction. Various applications of aluminium products include bicycle frame, rudder of aircraft, truck frames, kitchen utensils, and food wrapper [1]. It is favoured in industry owing to the excellent combination of high strength-to-weight ratio and excellent mechanical properties such as hardness and good machinability found in various series of aluminium alloy [2]. Aluminium alloy consists of different elements with different chemical compositions where the Aluminium is the dominant component with different main alloying elements. Different alloy elements in the composition of aluminium alloys determine its characteristics and properties. Among the Aluminium alloy groups, Al 7075 containing 5.6\% Zinc in weight of Aluminium was marked as the highest strength of Aluminium alloy with $570 \mathrm{MPa}$ tensile strength, comparable to other steels [3]. The research claimed that, aluminium alloy has its drawbacks in machining operation despite its high machinability. The formation of a built-up edge (BUE) tends to affect the machined surface and alter the cutting tool geometry. BUE also tends to increase the tool wear significantly [3]. Thus, numerous studies were conducted in order to minimize the problem encountered during machining aluminium alloy and solve the critical issues. Recently, many studies were done on aluminium alloy to investigate its machinability. Researchers are looking into various machining parameters on some criteria such as tool life, chip formation, and surface roughness to provide a vast overview on the machinability of aluminium alloys [4]. Nevertheless, research on the cutting tool analysis and performance is a bit lacking compared to the study on the surface integrity and optimization of cutting conditions especially for turning operations. Most of the research concentrated on the milling operation. Therefore, further studies on this problem are necessary, particularly in turning operations. This study aims to evaluate the cutting tool performance in terms of tool wear rate, wear mechanism, volume of material removed, and the quality of machined surface in dry turning Al 7075-T651 aluminium alloy using KW10 Kyocera uncoated carbide tool. 


\section{METHODOLOGY}

\subsection{Workpiece and Cutting Tool Material}

The workpiece material used in the machining tests was $100 \mathrm{~mm}$ x $200 \mathrm{~mm} \mathrm{Al} \mathrm{7075-}$ T651 cylindrical bar. T651 is the tempered designation in which the material is solution heat treated, stress relieved, and artificially aged. The chemical composition and mechanical properties of the work material are given in Table 1 and Table 2, respectively.

Table 1: Chemical Composition of Al 7075 (\%wt)

\begin{tabular}{ccccccccl}
\hline $\mathbf{S i}$ & $\mathbf{F e}$ & $\mathbf{C u}$ & $\mathbf{M n}$ & $\mathbf{M g}$ & $\mathbf{C r}$ & $\mathbf{Z n}$ & $\mathbf{T i}$ & Others \\
\hline 0.04 & 0.10 & 1.3 & 0.07 & $2.3-2.4$ & 0.10 & $6.7-6.8$ & 0.05 & Balance \\
\hline
\end{tabular}

Table 2: Mechanical properties of Al 7075

\begin{tabular}{cc}
\hline Properties & Values \\
\hline Tensile strength (ksi) & $78-85$ \\
Yield strength (ksi) & $68-78$ \\
Elongation $(\%)$ & $7-12$ \\
\hline
\end{tabular}

The cutting tool used was a KW10 Kyocera uncoated carbide tool with the ISO designation TNGG 160408AH. This cutting tool is suitable for use in cutting non-ferrous material such as Al 7075 for medium to finishing operations. The tool holder was selected according to the cutting tool with the ISO designation MTJNR 2525M-16.

\subsection{Machining Experiments}

The turning operation was conducted in dry conditions using a ROMI M420 CNC lathe machine. The parameters and values used in the experiment are shown in Table 3.

Table 3: Parameters used in the experiment

\begin{tabular}{cc}
\hline Parameters & Value \\
\hline Cutting speed $(\mathrm{m} / \mathrm{min})$ & 250,450 \\
Feed rate $(\mathrm{mm} / \mathrm{rev})$ & 0.05 \\
Depth of cut & 1.0 \\
\hline
\end{tabular}

The average tool flank wear, $V B_{\text {ave }}$ was measured using a Dino-Lite Edge Digital Microscope at $227 \mathrm{x}$ magnification at each 1 minute of the cutting time. The turning operation was then stopped when the cutting time reached 40 minutes. The recorded data was used to determine the tool flank wear progression with cutting time and tool wear rate for both cutting speeds. The wear also was used to calculate the volume of material removed within 40 minutes of machining time.

When 40 minutes of cutting time was achieved, the average surface roughness of workpiece $\left(\mathrm{R}_{\mathrm{a}}\right)$ was measured using a Mitutoyo Surftest surface roughness tester. The surface roughness of both cutting speeds were recorded and analysed.

Then, the cutting tool was examined under scanning electron microscope (SEM) JEOL JSM-5600 in order to determine the type of wear and wear mechanism that occurred during the machining operation. 


\section{RESULTS AND DISCUSSION}

\subsection{Effect of Cutting Speed On Tool Wear Rate and Volume of Material Removed}

Figure 1 shows the progression of flank wear versus cutting time for turning Al 7075T651 using KW10 uncoated carbide tool at cutting speed of $250 \mathrm{~m} / \mathrm{min}$ and $450 \mathrm{~m} / \mathrm{min}$, while other parameters are kept constant, as tabulated in Table 3. The average flank wear of uncoated carbide tool increased with the increase in cutting time within 40 minutes of cutting time.

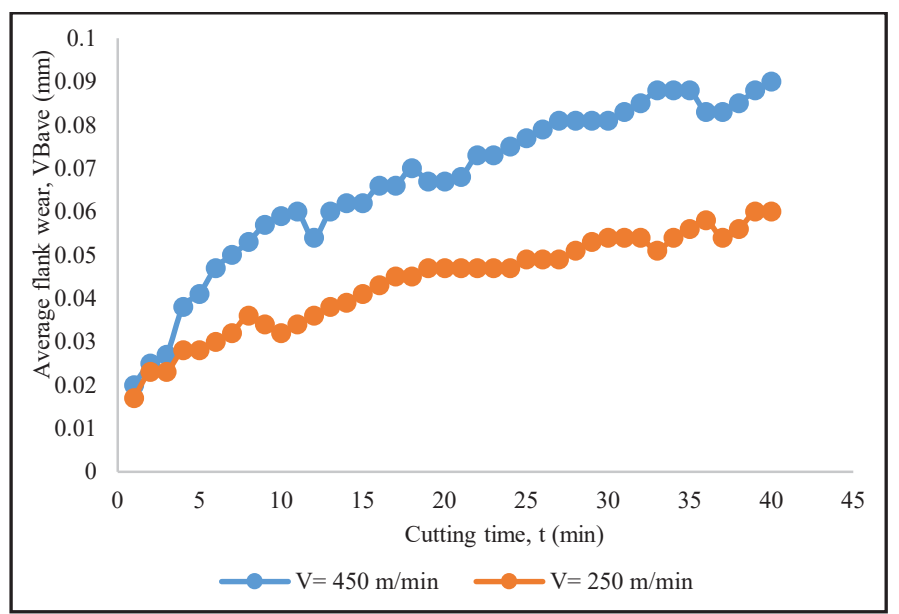

Fig. 1: Comparison of tool average flank wear progression versus cutting time at cutting speeds $250 \mathrm{~m} / \mathrm{min}$ and $450 \mathrm{~m} / \mathrm{min}$ in dry condition $(\mathrm{f}=0.05 \mathrm{~mm} / \mathrm{rev}, \mathrm{d}=1.0 \mathrm{~mm})$.

Although similar trends of flank wear were observed, it is noted that at 40 minutes of machining time, the uncoated carbide tool used at $450 \mathrm{~m} / \mathrm{min}$ had $50 \%$ higher average flank wear which is $0.090 \mathrm{~mm}$ compared to $0.060 \mathrm{~mm}$ of $V B_{\text {ave }}$ when cutting at 250 $\mathrm{m} / \mathrm{min}$. Due to that, it can be concluded that the uncoated carbide tool wears rapidly at high cutting speed especially on the flank face. This might be caused by the high intensity of cutting temperature at high cutting speed because of the rubbing of the tool and the machined surface and the sliding of the chip along the tool's rake face. This is supported with the findings by other researchers that were reviewed by [5], who stated that the increment of cutting speed results in higher rate of material deformation at the cutting zone, which consequently elevates the degree of heat generation hence accelerating the tool wear formation.

The graph presented in Fig. 1 has a similar trend to the tool wear growth curve that was reported in [6]. For 40-minutes machining time, the two phases of wear progression trend, which are break-in period and steady-state wear regions, can be observed. The rate of tool wear growth for each phase at both cutting speeds was calculated as shown in Table 4.

The rate of flank wear growth using a KW10 uncoated carbide tool in the first phase is higher than the second phase and the tool wear rate is relatively high at higher cutting speed $(450 \mathrm{~m} / \mathrm{min})$. This means that the wear occurred rapidly in the first phase, especially at high cutting speed. This rapid increment was due to the increase in the tool's material removal resulting from the elevation of the machining temperature. This result is aligned with the findings reported by [6] that some of tool materials can be removed easily when the cutting edge experienced high cutting temperature due to the high cutting speed. 
Table 4: The rate of flank wear growth using uncoated carbide tool

\begin{tabular}{lll}
\hline & \multicolumn{2}{c}{ Rate of Flank Wear Growth } \\
\hline Tool Wear Progression Phase & $\mathrm{V}=250 \mathrm{~m} / \mathrm{min}$ & $\mathrm{V}=450 \mathrm{~m} / \mathrm{min}$ \\
Break-in period (first phase) & $2.375 \mathrm{E}-3$ & $3.636 \mathrm{E}-3$ \\
Steady-state wear region (second phase) & $0.774 \mathrm{E}-3$ & $1.28 \mathrm{E}-3$ \\
\hline
\end{tabular}

The varied cutting speeds also have an influence on the volume of material removed in the turning operation. The volume of material removed was calculated using Eq. (1) at the same average flank wear, which is $0.060 \mathrm{~mm}$.

$v\left(m^{3}\right)=(\pi)\left(D_{\text {avg }}\right)(d)(f)(N) \times$ tool travel $($ min $)$

At cutting speed $250 \mathrm{~m} / \mathrm{min}$, the volume of material removed was found to be $507461.46 \mathrm{~mm}^{3}$ for 40 minutes of machining time $\left(V_{b_{\text {ave }}}=0.060 \mathrm{~mm}\right)$, whereas the volume of material removal at cutting speed $450 \mathrm{~m} / \mathrm{min}$ for 11 minutes of machining time $\left(V_{b_{\text {ave }}}=0.060 \mathrm{~mm}\right)$ was $296161.71 \mathrm{~mm}^{3}$.

The lower speed $(250 \mathrm{~m} / \mathrm{min})$ has $71 \%$ higher volume of material removal with longer cutting time compared to the high cutting speed $(450 \mathrm{~m} / \mathrm{min})$. According to Rao [8], they stated that the relationship between tool life and cutting speed affects the decrease of material removal rate (MRR). MRR is the volume of material removed per unit time. Hence, it can be decided that, the decrease of MRR leads to a decrease in material removal volume as the volume of material removed is directly proportional to MRR.

\subsection{Tool Wear and Wear Mechanism}

Table 5 shows the views of wear area for the KW10 uncoated carbide tool used in the machining test for 40 minutes under SEM. From Table 5, it can be noted that the flank wear, crater wear, and nose wear were found on the cutting tool edges for both cutting speeds within 40 minutes of the turning operation of Al 7075-T651 using KW10 uncoated carbide under dry conditions.

The flank wear occurred at the front relief and side relief faces, whereas the crater wear was formed at the rake face. The nose wear was formed at the nose area of the tool.Flank wear is the main type of wear observed in this machining experiment. The friction caused by the rubbing action of the tool and the machined surface resulted in high cutting temperature; thus, the flank wear formation was promoted [9]. Despite both cutting conditions having similar types of wear, the severity in tool wear formation differed. With the increment of cutting speed, the flank wear was affected and increased significantly.

The main wear mechanism observed in this study was adhesion wear mechanism. It was formed due to the high cutting temperature at the tool-chip interface during machining of aluminum alloy. The heat generation was influenced by the cutting speed. However, the effect of the cutting speed on the adhesion wear mechanism is not severely affected as the flank wear does.

Adhesion wear was formed due to the welding of the workpiece material which was concentrated at the rake, front relief, and side relief faces. The cutting temperature that was generated in both conditions was predicted to be high enough to melt the work material at the cutting interface. The welded material was then developed to form BUE. The tearing of unstable BUE from the cutting tool surface caused a small quantity of tool material to be removed. The frequent building and breaking away of BUE increased the high wear rate 
[7]. The result was in agreement with the findings reported by Jurado et al. [9], as the adhesion wear occurred when material was transferred by chip onto the tool surface and modified the cutting conditions.

Table 5: The views of wear area for KW10 uncoated carbide tool used in machining test at cutting speed at $\mathrm{V}=250 \mathrm{~m} / \mathrm{min}$ and $\mathrm{V}=450 \mathrm{~m} / \mathrm{min}$ after 40 minutes of cutting time

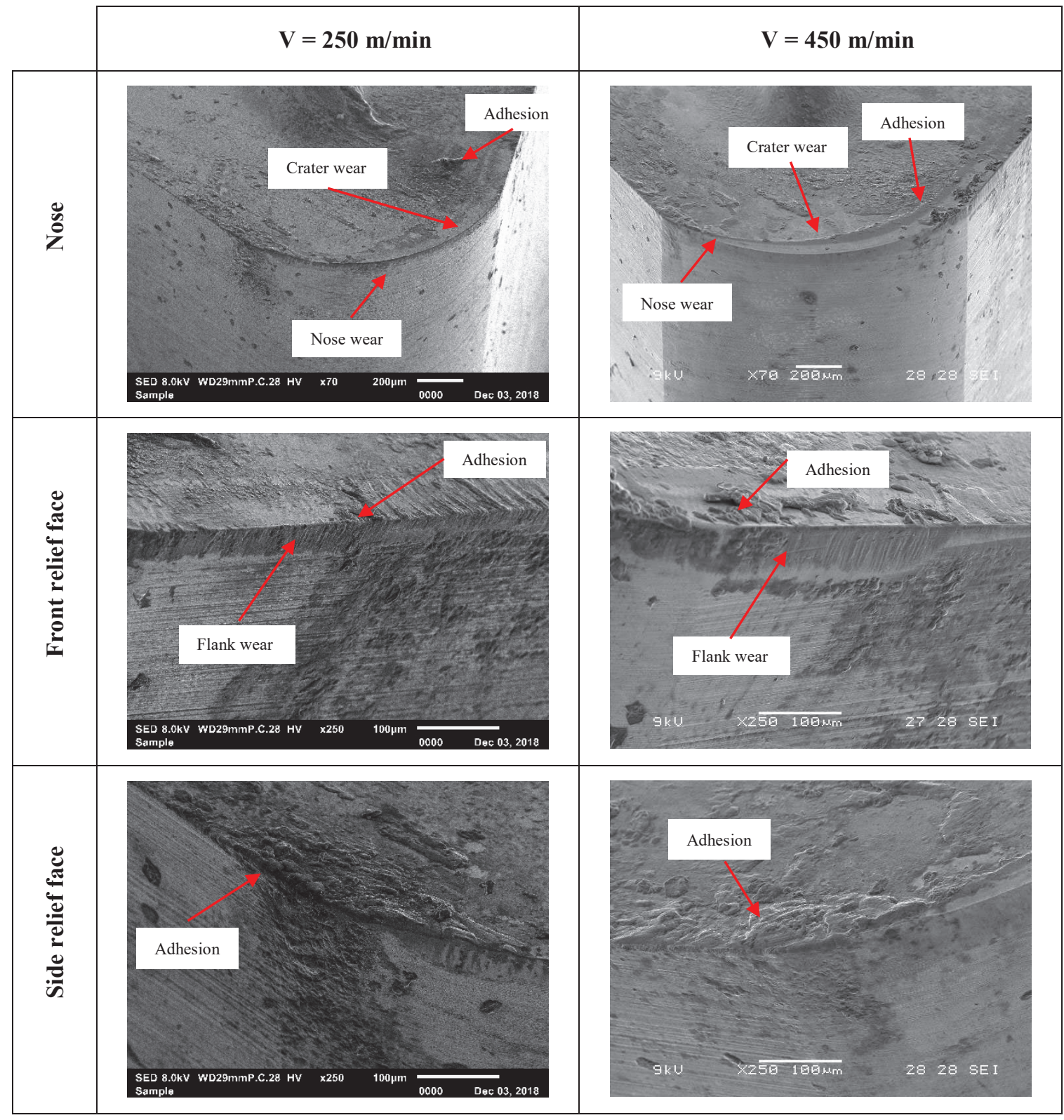

\subsection{Effect of Cutting Speed on Surface Roughness}

The surface roughness of the machined workpiece was measured to evaluate the cutting tool performance of the uncoated carbide tool in turning A1 7075-T651. Fig.2 shows the relationship between cutting speed and average surface roughness $\left(R_{a}\right)$ at 40 minutes of cutting time. 


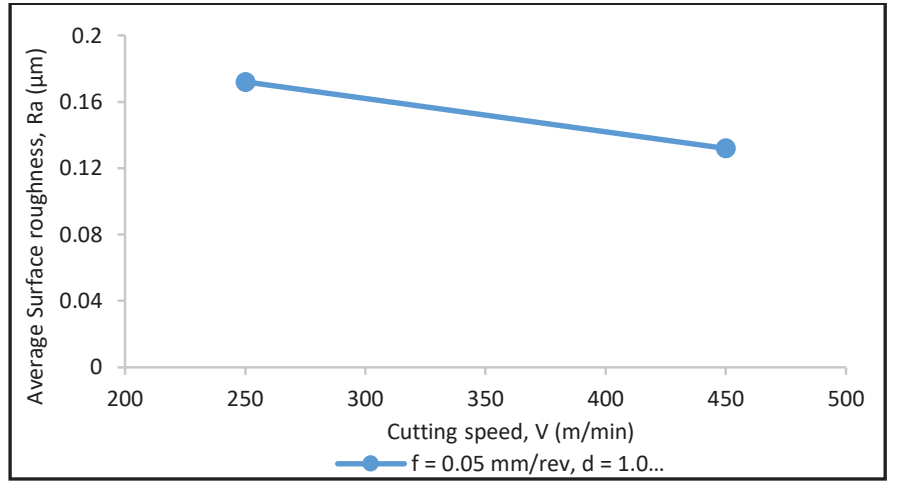

Fig. 2: The average surface roughness $(\mathrm{Ra})$ of the machined surface of $\mathrm{Al} 7075-$

T651 for cutting speeds $250 \mathrm{~m} / \mathrm{min}$ and $450 \mathrm{~m} / \mathrm{min}$ using the KW10 uncoated carbide tool at $\mathrm{t}=40$ minutes in dry conditions $(\mathrm{f}=0.05 \mathrm{~mm} / \mathrm{rev}, \mathrm{d}=1.0 \mathrm{~mm})$.

Referring to Fig. 2, the best surface finish was achieved at high cutting speed with $0.132 \mu \mathrm{m}$ within 40 minutes of cutting time. The surface roughness value produced decreased as the radius of chip curl increased with the increment of the cutting speed. Figure 3 shows the difference in degree of chip curl produced at cutting speed $=250 \mathrm{~m} / \mathrm{min}$ and $450 \mathrm{~m} / \mathrm{min}$ in turning A1 7075-T651.
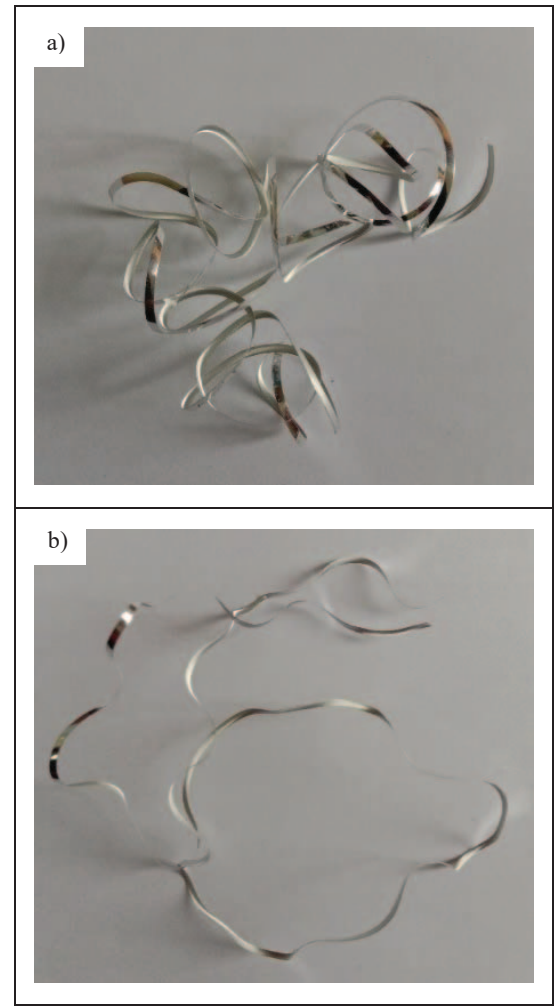

Fig. 3: Chips produced in turning Al 7075-T651 using a KW10 uncoated carbide tool under dry conditions, $\mathrm{f}=0.05 \mathrm{~mm} / \mathrm{rev}, \mathrm{d}=1 \mathrm{~mm}$ at, (a) $\mathrm{V}=250 \mathrm{~m} / \mathrm{min}$, and (b) $\mathrm{V}=450 \mathrm{~m} / \mathrm{min}$.

A high surface roughness was obtained due to this low radius of chip curl, which tends to tangle and accumulate around the machined surface and scratches the freshly cut workpiece. Consequently, the surface roughness increases as the accumulation of chips caused the unevenness in the machined surface. Similar findings were discussed by [10], 
the radius of the chip curvature increased with increase in the cutting speed which led to chips wrapping around the cutting tool, tool holder, and workpiece.

\section{CONCLUSION}

From the analysis on the cutting tool performance of KW10 uncoated carbide tool in turning Al 7075-T651, the following can be concluded:

- The tool at lower cutting speed $(250 \mathrm{~m} / \mathrm{min})$ performed better in having lower average tool wear rate within 40 minutes of operation. The percentage of average tool wear reduction was about $33 \%$ when turning at cutting speed $250 \mathrm{~m} / \mathrm{min}$ compared to $450 \mathrm{~m} / \mathrm{min}$.

- A rapid wear growth rate was achieved in the first phase (break-in phase) especially at a high cutting speed. The tool wear rate at cutting speed $250 \mathrm{~m} / \mathrm{min}$ is $34 \%-40 \%$ slower than the tool wear rate at $450 \mathrm{~m} / \mathrm{min}$ in both phases (break-in and steadystate wear phases). The rapid increment was due to the high intensity of cutting temperature at higher cutting speed.

- At the same average flank wear measurement, $\mathrm{V}_{\text {bave }}=0.6 \mathrm{~mm}$, the low cutting speed $(250 \mathrm{~m} / \mathrm{min})$ produced about $71 \%$ higher volume of material removed compared to high cutting speed $(450 \mathrm{~m} / \mathrm{min})$, in which high volume of material removed may increase the machining productivity.

- The most significant type of wear observed on the cutting edges in both conditions at $250 \mathrm{~m} / \mathrm{min}$ and $450 \mathrm{~m} / \mathrm{min}$ is the flank wear. The severity in tool wear formation increased with the increment of cutting speed.

- The main wear mechanism identified was adhesion during the turning operation at both cutting speeds. The welded material on the cutting edge caused the adhesion to form in all conditions. The building and tearing of BUE promotes higher tool wear.

- The KW10 uncoated carbide tool used in turning Al 7075-T651 at cutting speed $450 \mathrm{~m} / \mathrm{min}$ performed better than at $250 \mathrm{~m} / \mathrm{min}$ in producing low surface roughness due to the high radius of chip curl. It has low tendency for the chip to tangle around the freshly cut surface of the workpiece and leave scratches and marks on it.

\section{ACKNOWLEDGEMENTS}

This project is supported by the Government of Malaysia and the International Islamic University Malaysia under these research grants, FRGS/1/2018/TK03/UIAM/03/4 and RIGS17-157-0732.

\section{REFERENCES}

[1] Ng CH, Yahaya SN, Majid AA. (2017) Reviews on aluminum alloy series and its applications. Academia Journal of Scientific Research, 708-716.

[2] Das DK, Mishra PC, Sahoo AK, Ghosh D. (2015) Experimental investigation on cutting tool performance during turning AA 6063 using uncoated and multilayer coated carbide inserts. International Journal of Machining and Machinability of Materials, 17(3/4):277.

[3] Santos MC, Machado AR, Sales WF, Barrozo MAS, Ezugwu EO. (2016) Machining of aluminum alloys: a review. International Journal of Advanced Manufacturing Technology, 86(9-12):3067-3080. 
[4] Kouam J, Songmene V, Balazinski M, Hendrick P. (2015) Effects of minimum quantity lubricating (MQL) conditions on machining of 7075-T6 aluminum alloy. The International Journal of Advanced Manufacturing Technology, 79(5-8):1325-1334.

[5] Santos MC, Machado AR, Barrozo MAS. (2018) Temperature in Machining of Aluminum Alloys. Temperature Sensing.

[6] SV Alagarsamy NR. (2014) Analysis of Influence of Turning Process Parameters on MRR \& Surface Roughness Of AA7075 Using Taguchi's Method and Rsm. International Journal of Applied Research and Studies, Volume 3(4):1-8.

[7] Zagórski I, Warda T. (2018) Effect of Technological Parameters on the Surface Roughness of Aluminium Alloys After Turning. Advances in Science and Technology Research Journal, 12(2):144-149.

[8] Rao CJ, Sreeamulu D, Mathew AT. (2014) Analysis of Tool Life during Turning Operation by Determining Optimal Process Parameters. Procedia Engineering, 97:241-250.

[9] Jurado DG, Martínez JMV, Gámez AJ, Batista M, Puerta FJ, Marcos M. (2017) Analysis of secondary adhesion tool wear effects on surface roughness in dry turning process of UNS A92024 aluminium alloy. International Journal of Mechatronics and Manufacturing Systems, 10(1):23.

[10] Xu D, Feng P, Li W, Ma Y, Liu B. (2014) Research on chip formation parameters of aluminum alloy 6061-T6 based on high-speed orthogonal cutting model. International Journal of Advanced Manufacturing Technology, 72(5-8):955-962. 